\title{
Use of intracameral tenecteplase for rapid resolution of intraocular fibrin in acute anterior uveitis
}

Lee Wen Yee ${ }^{1,2}$, Teh Wee Min ${ }^{2,3}$, Ling Kiet Phang ${ }^{2,4}$, Norlina Mohd Ramli1 ${ }^{1}$, Haslina Mohd Ali

${ }^{1}$ Department of Ophthalmology, University of Malaya, Petaling Jaya, Selangor, Malaysia; 'Department of Ophthalmology, Hospital Sultanah Bahiyah, Alor Setar, Kedah, Malaysia; ${ }^{3}$ Department of Ophthalmology, Hospital Selayang, Selangor, Malaysia; ${ }^{4}$ Department of Ophthalmology, Hospital Sultanah Aminah, Johor Bahru, Johor, Malaysia

\section{Abstract}

Two patients presenting with acute anterior uveitis (AAU) and severe fibrinous reaction in the anterior chamber were given an injection of intracameral tenecteplase (50 microgram/0.1 ml). In both patients with AAU, complete rapid fibrin resolution and synechiolysis occurred within three days after intracameral tenecteplase injection. Significant visual acuity improvement was also seen in both patients and there were no complications observed throughout the follow-up duration of up to six months after administration of treatment. As tenecteplase has many superior properties compared to other medications in its class and can also be diluted and stored for up to a year under specific conditions, it may be an efficacious, safe and cost-effective means of treating severe AAU with fibrin formation.

Keywords: anterior uveitis, intraocular fibrin, tenecteplase, tissue plasminogen activator

Correspondence: Lee Wen Yee, MD, Department of Ophthalmology, University of Malaya, Petaling Jaya, Selangor, Malaysia.

E-mail: leewenyee87@gmail.com 


\section{Penggunaan tenecteplase intrakameral untuk pengurangan pantas fibrin intraokular dalam uveitis anterior akut}

\section{Abstrak}

Abstrak Uveitis anterior akut (AAU) dan reaksi fibrin yang teruk di dalam ruang anterior dilihat pada dua pesakit. Mereka diberi suntikan tenecteplase secara intrakameral (50 mikrogram / $0.1 \mathrm{ml}$ ). Kedua-dua pesakit dengan AAU ini menunjukkan pengurangan fibrin yang pantas dan penguraian sinaeke berlaku dalam tempoh tiga hari selepas suntikan tenecteplase intrakameral. Peningkatan ketajaman visual yang ketara juga dilihat pada kedua-dua pesakit dan tidak ada komplikasi yang diamati sepanjang tempoh tindakan dilanjutkan sehingga enam bulan selepas rawatan. Oleh kerana tenecteplase mempunyai banyak sifat unggul berbanding dengan ubat-ubatan lain di dalam kelasnya dan juga boleh dicairkan dan disimpan sehingga satu tahun di bawah keadaan tertentu, ia mungkin merupakan cara yang berkesan, selamat dan kos efektif untuk merawat AAU yang teruk dengan pembentukan fibrin.

Kata kunci: aktivator plasminogen tisu, fibrin intraocular, tenecteplase, uveitis anterior

\section{Introduction}

Anterior uveitis (AU) is the commonest form of intraocular inflammation. The formation of a massive fibrin clot in the anterior chamber can cause adverse functional and structural changes in the integrity of the eye.

Tissue plasminogen activator (t-PA) is safe and effective in rapid resolution and clearance of intraocular fibrin in humans. ${ }^{1}$ Tenecteplase (known commercially as TNK or Metalyse, Boehringer Ingelheim, Sydney, Australia) is a clot-specific fibrinolytic agent that can be produced by recombinant DNA technology, and its activity increases significantly in the presence of fibrin. ${ }^{2}$ Herein we report our experience with two patients who received intracameral TNK for severe fibrin formation in acute anterior uveitis (AAU). 


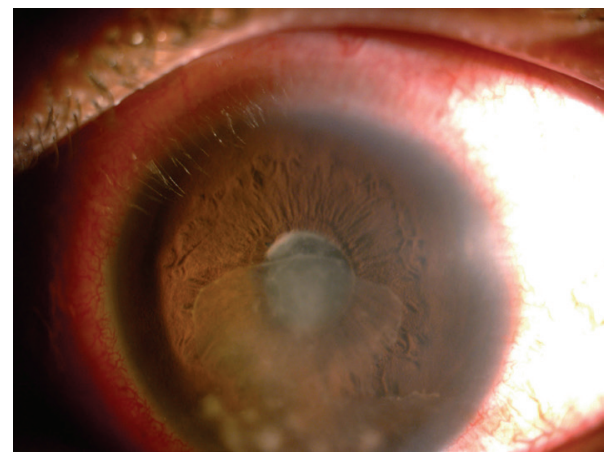

Fig 1. Severe fibrinous exudation with clumping inferiorly and almost $360^{\circ}$ of posterior synechiae obscuring the pupil.

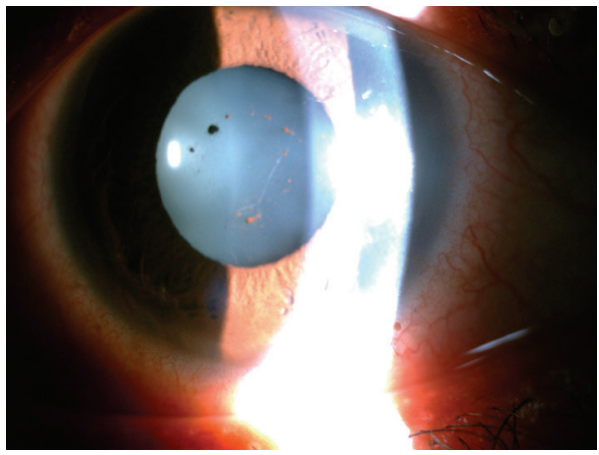

Fig 2. Complete fibrin resolution as well as synechiolysis within three days of injecting one dose of intracameral TNK (50 micrograms $/ 0.1 \mathrm{ml})$.

\section{Materials and methods}

Approval for the off-label intraocular use of TNK was obtained from the Pharmaceutical Services Division, Ministry of Health Malaysia in May 2017. Written informed consent was obtained from each patient before intraocular injection of TNK.

TNK was prepared for intraocular use by the in-house pharmacist in the following steps. One vial of powder contained 10,000 units (50 mg) of TNK. The powder was reconstituted with $10 \mathrm{ml}$ of water for injection from a pre-filled syringe under aseptic technique. The reconstituted solution contained 1,000 units (5 mg) of TNK per $\mathrm{ml}$. One milliliter of TNK solution was then diluted with another $9 \mathrm{ml}$ of balanced salt solution to obtain a final concentration of 50 micrograms $/ 0.1 \mathrm{ml}$. Each vial of TNK can be reconstituted into at least 300 units of $1 \mathrm{cc}$ syringes, with each syringe containing $0.3 \mathrm{ml}$ of TNK. To retain the fibrinolytic activity, aliquots can be kept for up to four weeks if kept at a temperature of $-20^{\circ} \mathrm{C}$ (or up to a year if kept at $-80^{\circ} \mathrm{C}$ ) and thawed just before use. Once liquefied, the solution had to be used within 24 hours.

Intracameral injections of TNK were performed in the following manner: The eye was anaesthetized with topical proparacaine. The skin was cleaned with $10 \%$ povidone-iodine solution and draped. The cornea and conjunctiva were irrigated with $5 \%$ povidone-iodine solution. A 30 -gauge needle on a tuberculin syringe was passed through the clear cornea at the limbus and $0.1 \mathrm{ml}$ of TNK solution (50 micrograms) was injected into the anterior chamber. The patients were examined at the slit lamp from day one post-injection until the fibrinous membrane had resolved and post-injection photographs were obtained. 


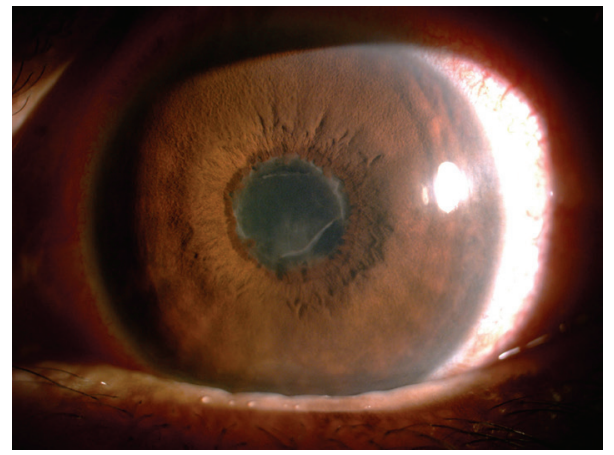

Fig. 3. Fibrinous membrane formation seen at the pupillary margin of the left eye, with almost complete $360^{\circ}$ posterior synechiae.

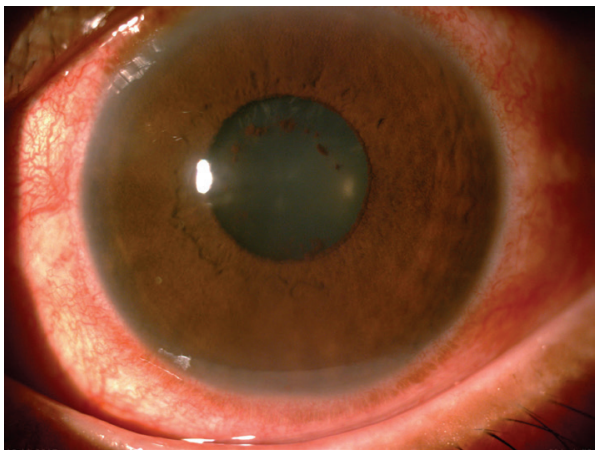

Fig. 4. At day one after injection of intracameral TNK (50 microgram $/ 0.1 \mathrm{ml}$ ), the pupillary membrane had dissolved and posterior synechiae completely broken off, leaving behind an imprint of iris pigments on the anterior lens capsule.

\section{Results}

\section{Case 1}

A 28-year-old male presented with left eye redness, pain, and decreased vision for ten days. Further history noted he also experienced on and off right-sided lower backache for the past three years. Visual acuity was hand motion. There was severe fibrinous exudation with almost $360^{\circ}$ of posterior synechiae (Fig. 1). B-scan showed clear vitreous without scleral thickening. Musculoskeletal examination revealed tenderness at the right sacroiliac area with positive FABER test. Diagnosis of left eye severe AAU with sacroiliitis was made. He was initially treated with frequent steroid eye drops as well as subconjunctival mydricaine without much improvement. He then received one dose of intracameral TNK (50 micrograms/0.1 ml), which resulted in complete fibrin resolution and synechiolysis within three days (Fig. 2). No adverse events occurred after the injection. Refracted vision at six months was 6/6.

\section{Case 2}

A 55-year-old female had left eye pain and redness for one week and blurred vision for two days. Visual acuity was counting fingers. There was fibrin in the anterior chamber with extensive posterior synechiae (Fig. 3). B-scan showed no vitreous opacity. Diagnosis of left eye AAU with seclusio pupillae was made. Patient was started on intensive topical steroids and cycloplegic agent followed by intracameral TNK (50 micrograms/0.1 ml), which resulted in complete fibrin resolution as well as synechiolysis within one day (Fig. 4). No adverse effects were observed.

At three months follow-up, her vision improved to 6/9. There was mild cataract noted. 


\section{Discussion}

Anterior uveitis is the most common form of intraocular inflammation. Fibrin may be present in the anterior chamber in severe forms of AU, and it may take weeks for the fibrin to completely resolve. The treatment of intraocular fibrin usually involves topical and systemic steroids that function to suppress inflammation; cycloplegics to decrease the risk of posterior synechiae formation and to relieve the painful ciliary spasm; and non-steroidal anti-inflammatory drugs (NSAIDs) to establish the blood ocular barrier by its anti-prostaglandin effect. ${ }^{3}$

The effects of conventional treatment for fibrinous membranes in AU mentioned above may only be apparent after at least one week of therapy. Thus, other treatment options for rapid resolution of fibrinous membrane are indicated before long-term complications develop. t-PA is an option for intraocular fibrinolysis and it is a 70000dalton protein that plays an important role in the fibrinolytic cascade by converting plasminogen to plasmin in the presence of fibrin. ${ }^{3}$ It has been shown to be safe and efficacious for the resolution of intraocular fibrin after vitrectomy, cataract surgery, glaucoma filtering surgery, and penetrating keratoplasty. ${ }^{1,4}$

Tenecteplase is a new thrombolytic agent which has a slower systemic clearance compared to other t-PAs. Its other properties include:

1. a longer half-life (20 minutes) and greater fibrin specificity;

2. more resistant to inactivation by plasminogen activator inhibitor 1 (PAI-1);

3. contains less than one-third the L-arginine content (implicated in retinal toxicity) of alteplase; and

4. less bleeding complications. ${ }^{5}$

One vial of TNK (10,000 U / $50 \mathrm{mg})$ can be reconstituted into about 300 aliquots of $1 \mathrm{cc}$ syringes, with each syringe containing $0.3 \mathrm{ml}$ of TNK. To retain the fibrinolytic activity, aliquots can be kept for up to a year at a temperature of $-80^{\circ} \mathrm{C}$ and thawed just before use. ${ }^{6}$ Once thawed, TNK retained $83-100 \%$ bioactivity even after 24 hours.

Our two cases demonstrated that TNK rapidly cleared fibrin from the anterior chamber and was also effective in synechiolysis in severe AAU within one to three days of its administration.

A review of available literature shows that the safe and effective dose of TNK ranged from 10 micrograms to 50 micrograms, with no evidence of retinal toxicity when 50 micrograms was injected subretinally. ${ }^{7}$ Fifty micrograms in $0.1 \mathrm{ml}$ of tenecteplase was given intracamerally in our cases uneventfully.

Haemorrhage is a major complication which occurs in up to $30 \%$ of patients treated with intravenous t-PA. However, only small doses of t-PA are used in intraocular injection; thus, systemic bleeding is rare. However, there is still a small risk of hyphaema and vitreous haemorrhage. Other adverse events like band keratopathy and intraocular lens opacification following intracameral application of t-PA have been reported..$^{8}$ Our patients were followed up for six months and three months, respectively, with no adverse event was observed throughout. 


\section{Conclusion}

Intracameral tenecteplase is effective for rapid resolution of fibrin and synechiolysis in AAU. However, in view of the lack of clinical trials with adequate sample size, we recommend intracameral tenecteplase be reserved for eyes with AAU and severe fibrin formation unresponsive to conventional therapy.

\section{Acknowledgements}

We would like to acknowledge the assistance and feedback given to us by the Department of Pharmacy, Hospital Sultanah Bahiyah, Alor Setar, Kedah, Malaysia.

\section{References}

1. Erol N, Özer A, Topbas S, Yildirim N, Yurdakul S. Treatment of intracameral fibrinous membranes with tissue plasminogen activator. Ophthalmic Surg Lasers Imaging Retina. 20031;34(6):451-456. doi:10.3928/1542-8877-20031101-04.

2. Pennica D, Holmes WE, Kohr WJ, Harkins RN, Vehar GA, Ward CA, Bennett WF, Yelverton E, Seeburg $\mathrm{PH}$, Heyneker HL, Goeddel DV. Cloning and expression of human tissue-type plasminogen activator cDNA in E. coli. Nature. 1983;301(5897):214.

3. Dotan A, Kaiserman I, Kremer I, Ehrlich R, Bahar I. Intracameral recombinant tissue plasminogen activator (r-tPA) for refractory toxic anterior segment syndrome. Br J Ophthalmol. 2014;98(2):252-255.

4. Jaffe GJ, Abrams GW, Williams GA, Han DP. Tissue plasminogen activator for postvitrectomy fibrin formation. Ophthalmology. 1990;97(2):184-189. doi:10.1016/S0161-6420(90)32618-0

5. Kwon YH, Lim SJ, Jeung WJ, You YS, Kim SH, Kwon OW. Subretinal tenecteplase injection in a submacular hemorrhage from polypoidal choroidal vasculopathy: a case report. Retin Cases Brief Rep. 2012;6(4):400-405.

6. Ortega-García MP, Blasco-Segura P. Elaboration of preloaded syringes of tenecteplase for treatment of central renal vein occlusion. Hospital Pharmacy Europe Issue 34 September/October 2007. Available at: http://www.hospitalpharmacyeurope.com/featured-articles/elaboration-preloaded-syringes-tenecteplase-treatment-central-renal-vein-occlusion. Accessed June 23, 2019.

7. McAllister IL, Vijayasekaran S, Khong CH, Yu DY. Investigation of the safety of tenecteplase to the outer retina. Clin Exp Ophthalmol. 2006;34(8):787-793. doi:10.1111/j.1442-9071.2006.01369.x.

8. Fung SS, Sykakis E, Islam NM, et al. Intraocular lens opacification following intracameral injection of recombinant tissue plasminogen activator to treat inflammatory membranes after cataract surgery. J Ophthalmol. 2015;2015:975075. doi:10.1155/2015/975075. 